EPiC Series in Biological Sciences
Volume 1, 2021, Pages 1-7
$\begin{gathered}\text { Proceedings of KOBI 2nd International Confer- } \\ \text { ence on Management of Tropical Biodiversity for } \\ \text { Human Welfare: From Ecosystem to Molecular }\end{gathered}$

\title{
The Giant Nypa Palm Worm Namalycastis rhodochorde (Polychaeta: Nereididae) in West Kalimantan: Reproduction and Aquaculture Studies
}

\author{
Junardi ${ }^{*}$ \\ ${ }^{1}$ Tanjungpura University, Pontianak, West Kalimantan, Indonesia \\ junardiefmipa.untan.ac.id
}

\begin{abstract}
West Kalimantan shows many reproductive events of Nereidid worms in estuaries. The Peniti and Karimunting estuaries become a Nereidid mass spawning site every year. Other estuaries such as the Kapuas river is also the one habitat of the Nereidid worm called the giant Nypa palm worm, Namalycastis rhodochorde. This species has a magnificent length in body size and popular use for fishing bait. The high demand for this worm causes habitat destruction and decreases the population in nature so cultivation efforts are important to do. Basic data encompassing habitat characteristics, reproduction, feeding, development, and larval rearing to enhancing cultivation has been obtained. Larval and juvenile stocking densities including aquarium installations are currently being studied in the laboratory. Further studies on harvesting techniques, specific pathogen-free (SPF) products as well as a sustainable production need to be carried out at industrial aquaculture level.
\end{abstract}

\section{Introduction}

West Kalimantan has three main rivers namely the Kapuas River, the Sambas River, and the Pawan River. The total tributaries of the three main rivers are 77 tributaries with water flowing out of the Java and South China Seas. These rivers are used by the community for various activities such as household needs, transportation, tourism, settlement, agriculture, and fisheries. Meanwhile, these estuaries are also the natural habitat for important aquatic biota, one of which is the high diversity of Polychaeta, for example, 44 species in the Peniti River estuary (Junardi \& Wardoyo, 2008). In addition, river estuaries also serve as a place for sexual reproduction of Nereid species at certain months of the year such as those found in the Peniti and Karimunting rivers. Human activities in these rivers have caused a decrease in water quality (Purnaini et al, 2017) and their habitat which also affects their biota. 
The Kapuas River as one of the main rivers also has an estuary which is an important habitat for Nypa palm worms (Namalycastis rhodochorde) (Glasby, et al, 2007). This worm has been used by the people of West Kalimantan as bait for fishing. The character of his long, pink, and greasy body is preferred over other live bait. The specific habitat for Nypa palm worms is only found in the mud around the Nipah plant (Nypa fruticans). This species is taken directly from its habitat by digging and then sold in traditional markets with prices ranging from IDR 6,000-20,000 per individual.

Until now, Polychaeta cultivation is only carried out on a small scale by some hatcheries industry only for their own feed needs, not yet on a large scale. Most of the polychaete's needs are imported from other countries such as England and the Netherlands. Data from the Directorate General of Aquaculture in 2012 stated that imports of frozen polychaetes up to 2,550 tons with a value of US $\$ 17,973.80$ (Rasidi, 2013). Among worm-seeking farmers, the price for fresh-caught worms caught from nature at hatcheries in Indonesia ranges from IDR 20,000-50,000 per kilogram (Rasidi, 2013). The results of a 2015 survey on the east coast of Lampung, farmers sell in small packages for IDR 10,000 per 500 grams.

The condition of the population is currently experiencing a decline which is known from the number of worms catches by collectors which are getting smaller every day. The decrease in the number of Nypa palm worms was caused by the conversion of land into plantations, taking Nipah plant for human needs, and taking it continuously every day. Cultivation can be a solution to reduce population decline due to habitat destruction. Basic biological data such as reproduction, development, feed preferences, and habitat are needed for cultivation. This article discusses aspects of reproduction and aquaculture as reference data for mass production of Nypa palm worms $N$. rhodochorde.

\section{Reproductive Studies of Nypa Palm Worm}

Until now, scientific data on the reproduction of this Nypa palm worm species in Indonesia is still limited to the process of gamete formation and aspects of reproduction and gametogenesis (Junardi, et al, 2010). N. rhodochorde worms have one sex in one individual so that male and female individual can be determined. Sexual dimorphism is only recognized if the individual has entered the sub mature stage based on the gamete characters taken from the body's cell, but morphologically, the sex differences do not show any differences.

In the sub mature stage, the female has an egg size between 70-100 $\mu$ m. Furthermore, when mature, the female will have a uniform egg size $>120 \mu \mathrm{m}$, with brown and round shape. Mature eggs are characterized by the number of fat granules in them (Figure 1A.) The egg size in Namalycastis is generally smaller than Namanereis although it is still included in the Sub Family of Namanereidinae. The smallest mature egg size was owned by $N$. fauvelii with a diameter of $84.20 \mu \mathrm{m}$, while the largest mature oocyte was found in $N$. intermedia and $N$. nicoleae, each with a diameter of $>300 \mu \mathrm{m}$ (Glasby, 1999). The smallest diameter size of Namanereis mature eggs was $115 \mu \mathrm{m}$ in $N$. hummelincki and the largest oocyte size of $640 \mu \mathrm{m}$ was found in N. quadraticeps. (Glasby, 1999; Johnson, 1908). The increase in the diameter of the oocyte from the initial stage occurs due to the accumulation of nutrients consisting of lipid droplets, glycogen granules, and yolk in the ooplasm (Eckelbarger, 2005). 

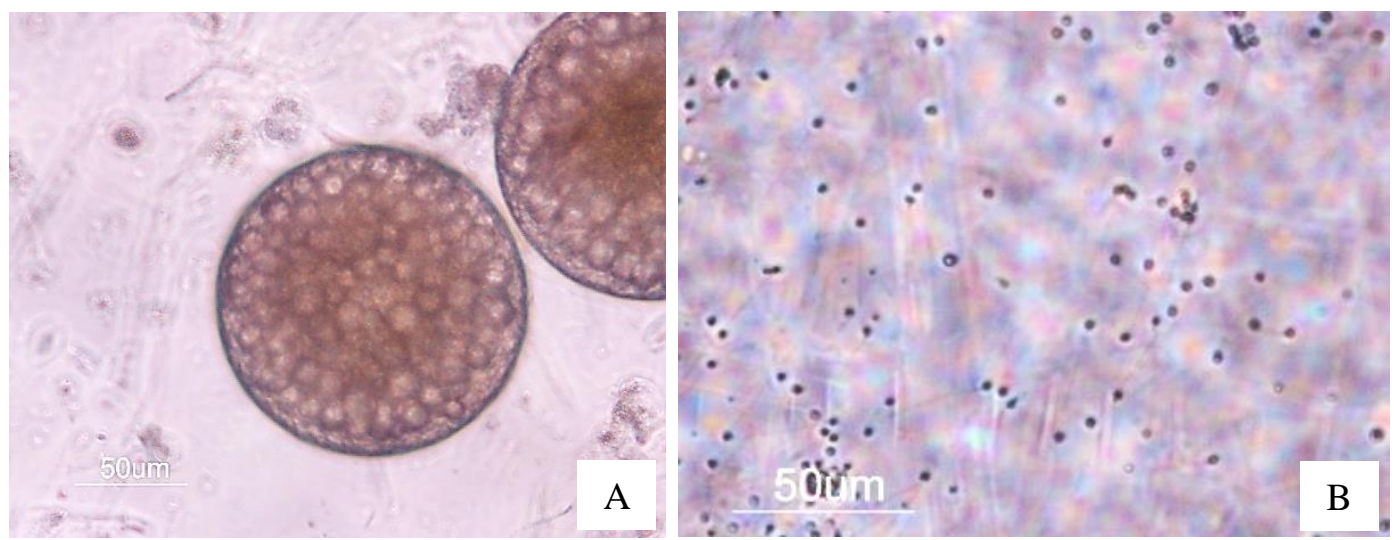

Figure 1: Gamet of Nypa palm worm N. rhodochorde, Egg (A) and Spermatozoa (B)

Eggs are released and differentiated in the body's cells. Meanwhile, spermatozoa are also easier to recognize if the spermatogonia cluster in the coelom has turned into spermatids. At this stage, the sperm are clustered into small clusters of 4 sperm or sperm tetrads (Figure 1B), before finally separating and becomes one free-moving spermatozoa.

Polychaeta gametogenesis is divided into three patterns, first, the gametes are formed and developed in the gonads and the second primordial gametes originate from body cells then undergo proliferation and develop in the coelom, and the third pattern is combined from the first and second patterns (Eckelbarger, 2005). In N. rhodochorde, gametes are formed following the second pattern, oocytes and sperm develop inside the coelom.

Morphological differences between males and females were found after entering the mature stage. The male has a pale body color and the ventral part of the body is greenish, while the female's body changes from pink to brownish red. The difference in morphological characters is due to the influence of differences in the color of each gamete. Visually, it can be easily distinguished between the two because the body's tissues are thinned or transparent, making it easier to release gametes to the body. Nypa palm worms do not have gonads as organs for storing gametes, so that gamete respiration is done by rupture of the body wall so that mature individual will die after releasing their shakes outside the body. This type of reproduction is better known as the semelparity type which is generally found in the Nereididae family.

Maturity in Nereididae can be grouped into two, heteronereid and non-heteronereid. Species that are included in heteronereid will modify parapodia and seta to do swarming, moving from the sediment to the surface of the water to release the individual gametes in this group which is also called epitokous. At first, parapodia were round-shaped, while at maturity they were flat. Seta is also initially round, tapered, then when it is mature, it looks like a paddle, so it is called paddle-shaped setae. Another organ that changes during maturation in heteronereid Polychaeta is the eye which becomes bigger than before, but this was not found in $N$. rhodochorde.

Research on the existence of reproductive hormones and energy allocation for reproduction has also been carried out by Junardi (2014) who found progesterone, estrogen, and estradiol. The concentration of these hormones continues to increase as the Nypa palm worms mature. The reproductive energy allocation in $N$. rhodochorde reached $69 \%$ as measured in mature individuals. Reproductive energy was found to have a strong correlation with the developmental stage but not with body length.

Indicators of high energy allocation can be observed through fecundity and oocyte size (Kupriyanova, 2001). In N. rhodochorde, mature females had an average oocyte count of 1.09 x 106 oocytes $/ \mathrm{ml}$. Total $N$. rhodochorde oocytes reached an average of 72.79 x 106/individual females. The sperm count in male $N$. rhodochorde averaged $3.85 \times 109$ cells $/ \mathrm{ml}$ with a total sperm count of $66.03 \times$ 
109 cells/individual. Fecundity of these worms is strongly correlated with body length because the eggs released and developed in the body coils are found throughout the body.

Research conducted in 2011-2012 found that the sex ratio (female: male) of $N$. rhodochorde worms in their natural habitat was between 1: 1-1:2. Females are found more than males. The results of the sex ratio study have been reviewed by Scaps (2002) who found that Nereis diversicolor also has a sex ratio that is almost the same as more females.

\section{Aquaculture Study of Nypa Palm Worm}

Research related to Nypa palm worm cultivation has been carried out in Indonesia, among others, by Rasidi \& Patria (2012) who took worms from Nereis sp. from nature and maintain it in the laboratory without going through the stages of fertilization and larval enlargement. Trisyani \& Wuwung (2014), Hermawan et al. (2015), and Hermawan, Saifullah, \& Herdiyana (2015) also do the maintenance of worms for Neries sp. which is also taken directly from nature to determine the effect of different stocking densities and salinity on the survival of worms also without going through larval spawning and rearing.

Similar research was also carried out by Mustofa et al. (2012) by maintaining Polychaeta but from the Dendronereis pinnaticirris species taken from nature. Other research on D. pinnaticirris worms starting from the spawning and development of larvae in the laboratory was carried out by Wibowo et al. (2020). Research on the spawning and rearing of Namalycastis larvae in Indonesia is currently not available

\subsection{Fertilization}

The results of artificial fertilization showed that $N$. rhodochorde fertilization could occur in the salinity range between $7-21 \%$. The temperature when this experiment was carried out was adjusted according to the room temperature between $25-29^{\circ} \mathrm{C}$. The best salinity ranges for successful fertilization occurred in media with a salinity of $12-13 \%$. The salinity range is almost the same as the salinity range at the time of spawning in the field in May-July, which is between 5-22\%o.

The success of the fertilized oocyte is also followed by the formation of trochophorous larvae in the salinity range of $10-11 \%$. The increase in salinity towards the seawater passage resulted in the formation of 3-setiger larvae steadily decreasing. Likewise, the decrease in salinity towards freshwater also results in decreased larval survival. The survival rate of trochophore larvae into 3-setiger larvae was only obtained at a salinity of $10 \%$.

The cross-section of the fertilization medium of $N$. rhodochorde was lower than the range of fertilization salinity and survival rate for larvae of scrotal worms (Dendronereis) with a salinity range of 15-17\% (Yuwono et al, 2002). This is because N. rhodochorde can live in an environment with salinity leading to freshwater (Glasby et al., 2007). Observations of fertilized eggs (fertile eggs) on $N$. rhodochorde had an average of $191.17 \pm 153.63$ cells. The fertilized egg (zygote) is first characterized by the formation of the fertilization membrane and the cleavage pole. ANOVA results showed that the number of fertile oocytes of the two species was not significantly different. The fertility value of $N$. rhodochorde had average fertility of $66.75 \pm 3.82 \%$. The fertility value will affect the difference in the number of fertile oocytes that have succeeded in becoming trochophorous larvae.

The number of trochophores of $N$. rhodochorde larvae averaged $51.91 \pm 19.91$ larvae which will affect the difference in the number of 3-setiger larvae. The viability of trochophore larvae that succeeded in becoming 3-setiger larvae on $N$. rhodochorde was only $1.00 \pm 1.47$ larvae on average. The low viability of the larvae is thought to be a reproductive strategy for $N$. rhodochorde by producing the number of eggs from one individual female so that these worms must have a longer body size to maximize gamete production to increase the value of fecundity and viability of larvae. The mortality of 
$N$. rhodochorde larvae in the early stage can be calculated from the unfertilized oocytes as much as $33.25 \%$, then until the trochophore larvae, the mortality continues to increase to $72.93 \%$ and finally to $99.57 \%$ in 3-setiger larvae. The factors causing the high mortality of $N$. rhodochorde were in addition to the low quality of eggs and sperm.

\subsection{Larval Development and Stocking Density}

The fertilization and larval development of $N$. rhodochorde is highly influenced by water salinity and temperature. Normal salinity of $22 \%$ was found for the development of polychaete Nereis virens (Ushakova \& Sarantchova, 2004). In this study, the salinity for fertilization and larval development before 3-chetigers ranged between $7-21 \%$. While, Perinereis rullieri, the salinity of $10 \%$ in the firstmonth experiment of survival was 60\% (Prevedelli \& Vandini, 1997). The difference in salinity depends on the species and locality for environmental adaptation. The cleavage and larval stage occurred respectively within 28.20 to 58.67 minutes and within $72-80$ hours after fertilization.

When the worms had reached 3-segmented (3-setigers) level, the worms were transferred to the nursery tank (37x26x14 cm) until the worms were 10 days old or at the nectochaeta stage (Figure 2A). The average increase was observed every day with an average increase of 1 setiger/day. The rearing of nectochaeta larvae was continued until the juvenile stage (Figure 2B). Feed while in the nursery tank was given $1 \mathrm{ml} / \mathrm{L}$ of Chlorella vulgaris culture twice a day, morning and evening, and 1 gram/tank of fermented palm fronds.

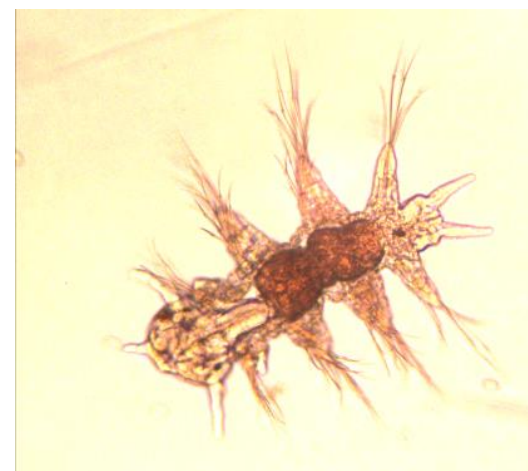

Figure 2: Nypa palm worm $N$. rhodochorde at stages of nectochaeta and juvenile

Research on the stocking density of larvae has been carried out with a density level of 50-250 larvae/tank with the same food and the same size of rearing containers and volume of water that get low stocking density to get the best survival and growth of larvae. Research related to stocking density has also been carried out on two types of feed, Sargassum seaweed, and fermented Nipah fronds. However, the results have not shown a significant difference in the survival and growth of Nypa palm worm larvae in the laboratory. Further research is still needed to obtain the best stocking density data for survival and larval growth.

\section{Further studies}

Further research is still needed related to aspects of feed, juvenile maintenance, and optimization of cultivation installations. Feed engineering, the environment, and the acceleration of reproductive hormones will be important points to speed up reproduction time so that the harvest period can be determined as needed without having to wait as in the natural environment. Other important data such 
as maintenance time and business analysis are needed to cultivate Nypa palm worms on an industrial scale, however, laboratory data will be the basic reference. The studies that have been carried out can be the answer to the second question that there have been and are still being made to cultivate Nypa palm worms even though they are still on a laboratory scale.

\section{Acknowledgments}

The authors wish to thank the Ministry of Research, Technology, and Higher Education of Indonesia for the dissertation research grant and Head of Zoology Laboratory Tanjungpura University for supporting laboratory facilities.

\section{References}

Eckelbarger K. (2005). Oogenesis and Oocyte, Hydrobiologia. Hydrobiologia, 535/536, 178-198.

Glasby CJ. (1999). The Namanereidinae (Polychaeta: Nereididae) Part 1, Taxonomy and Phylogeny. Records of the Australian Museum, Supplement 25: 1-129.

Glasby CJ, Miura T, Nishi E, and Junardi. (2007). A new species of Namalycastis (Polychaeta: Nereididae: Namanereidinae) from the shores of South-east Asia. The Beagle, Records of the Museums and Art Galleries of the Northern Territory, 23: 21-27.

Hermawan D, Mustahal, Suherna, and Juliarta IP. (2015a). Aplikasi Perbedaan Salinitas pada Pemeliharaan Cacing Laut (Nereis sp.). In Bahasa. Jurnal Ilmu Pertanian dan Perikanan, 4(1): 105112.

Hermawan D, Saifullah, and Herdiyana D. (2015b). Pengaruh Perbedaan Jenis Substrat Pada Pemeliharaan cacing Laut (Nereis sp.). Jurnal Perikanan dan Kelautan, 5(1): 41-47.

Johnson HP. (1908). Lycastis Quadraticeps, An Hermaphrodite Nereid with Gigantic Ova. The Biological Bulletin, 14: 371-386.

Junardi and Wardoyo ER. (2008). Struktur Komunitas dan Karakteristik Substrat Cacing Laut

(Polychaeta) di Perairan Pantai Mangrove Peniti, Kalimantan Barat. Biodiversitas, 9(3): 213-216.

Junardi, Anggraeni T, Ridwan A, and Yuwono E. (2014). The Maturity of nypa palm worm Namalycastis rhodochorde (Polychaeta: Nereididae). 1589, pp. 320-324. Bandung: AIP.

Junardi, Anggraeni T, Ridwan A, and Yuwono E. (2013). Early Ontogenesis of Small Nypa palm Worm Namalycastis Abiuma (Polychaeta: Nereididae); Proceeding of the International Symposium on Indonesian Biodiversity. (pp. 64-66). Purwokerto: Faculty of Biology, Jenderal Soedirman University.

Junardi, Setyawati TR, and Yuwono E. (2010). Gametogenesis Cacing Nipah Namalycastis rhodochorde (Polychaeta: Nereididae). In Bahasa. Jurnal Ilmu Dasar, 11(1): 39-44.

Kupriyanova EK. (2001). Live History Evolution in Serpulimorph Polychaetes: a Phylogenetic Analysis. Hydrobiologia, 496: 105-114.

Mustofa AG, Harris E, Supriyono E, and Jusadi D. (2012). Penggunaan Media Pasir untuk Budidaya Cacing Poliket Dendronereis pinnaticirris. In Bahasa. Jurnal Akuakultur Indonesia, 11(2): 118-123.

Prevedelli D and Vandini RZ. (1997). Survival and growth rate of Perinereis rullieri (Polychaeta, Nereididae) under different salinities and diets. Italian Journal of Zoology, 64: 135-139.

Purnaini R, Sudarmadji, and Purwono S. (2017). Kualitas Air Sungai Kapuas Kecil Bagian Hilir Pada Kondisi Pasang dan Surut. Seminar Nasional Penerapan Ilmu Pengetahuan dan Teknologi (pp. 1-9). In Bahasa. Pontianak: Universitas Tanjungpura.

Rasidi. (2013). Mengenal Jenis-jenis Cacing Laut dan Peluang Budidayanya Untuk Penyediaan Pakan Alami di Pembenihan Udang. In Bahasa. Media Akuakultur , 8(1): 57-62. 
Rasidi, \& Patria MP. (2012). Pertumbuhan dan Sintasan Cacing Laut Nereis sp. (Polychaeta, Annelida) yang Diberi Jenis Pakan Berbeda. Jurnal Riset Akuakultur, 7(3): 447-464.

Scaps, P. (2002). A Review of the biology, ecology, and potential use of the common Ragworm Hediste diversicolor (O.F. Müller) (Annelida: Polychaeta). Hydrobiologia, 470, 203-218.

Trisyani, N., \& Wuwung, D. (2014). Kelulushidupan Cacing Lur (Nereis sp) pada Padat Tebar yang Berbeda dengan Metode Resirkulasi. Seminar Nasional Kelautan IX (pp. 73-82). Surabaya: Universitas Hang Tuah Surabaya.

Ushakova, O. O., \& Sarantchova, O. L. (2004). The influence of salinity on fertilization and larval development of Nereis virens (Polychaeta, Nereidae) from the White Sea. , 301, 129-139. Journal of Experimental Marine Biology and Ecology, 301, 129-139.

Wibowo, E. S., Yuwono, E., Sukardi, P., \& Siregar, A. S. (2020). Survival Rate, Growth, and Chemical Content of Dendronereis pinnaticirris (Polychaeta, Nereidae) in Maintenance with Different Feeds and Substrates. Ilmu Kelautan: Indonesian Journal of Marine Sciences, 25(2), 75-84.

Yuwono, E., Haryadi, B., Susilo, U., Siregar, A. S., \& Sugiharto. (2002). Fertilisasi serta Pemeliharaan Larva dan Juvenil Sebagai upaya Pengembangan Teknik Budidaya Cacing Lur. Biosfera, 19(3), 20-26. 